medRxiv preprint doi: https://doi.org/10.1101/2021.12.13.21267744; this version posted December 14, 2021. The copyright holder for this preprint (which was not certified by peer review) is the author/funder, who has granted medRxiv a license to display the preprint in perpetuity.

All rights reserved. No reuse allowed without permission.

\title{
1 Ferritin trajectories over repeated whole blood donations: results from the FIND+ study
}

2 Sara Moazzen ${ }^{1}$, Maike G Sweegers ${ }^{1}$, Mart Janssen ${ }^{2}$, Boris M Hogema ${ }^{3}$, Trynke Hoekstra ${ }^{4}$, Katja van den Hurk ${ }^{1}$

3

5

6

7

8

9

10

1. Department of Donor Medicine Research, Donor Studies, Sanquin Research, Amsterdam, the Netherlands

2. Department of Donor Medicine Research, Transfusion Technology Assessment, Sanquin Research, Amsterdam, The Netherlands

3. Department of Donor Medicine Research, Blood-borne Infections, Sanquin Research, Amsterdam, The Netherlands.

4. Department of Health Sciences and Amsterdam Public Health Research Institute, Vrije Universiteit Amsterdam, Amsterdam, The Netherlands

\author{
Corresponding author \\ Katja van den Hurk \\ Plesmanlaan 125 \\ PO box 9137 \\ 1006 AC Amsterdam, the Netherlands \\ E-mail: k.vandenhurk@sanquin.nl
}

Funding: European Blood Alliance (EBA) Grant 2019

"Funding for this project has been provided in full or in part through an Agreement with the European Blood Alliance (EBA). The contents of this document do not necessarily reflect the views and policies of the EBA, nor does mention of trade names or commercial products constitute endorsement or recommendation of use." 
medRxiv preprint doi: https://doi.org/10.1101/2021.12.13.21267744; this version posted December 14, 2021. The copyright holder for this preprint (which was not certified by peer review) is the author/funder, who has granted medRxiv a license to display the preprint in perpetuity. All rights reserved. No reuse allowed without permission.

\section{Abstract}

35 Background: Whole blood donors lose approximately 200-250 mg of iron per donation. Depending 36 on post-donation erythropoiesis, available iron stores, and iron absorption rates, optimal donation 37 intervals may differ between donors. This project aims to define subpopulations of donors with 38 different ferritin trajectories over repeated donations.

39 Methods: Ferritin levels of 300 new whole blood donors were measured from stored (lookback) 40 samples from each donation over a two-year period in an observational cohort study. Latent classes of 41 ferritin level trajectories were investigated using growth mixture models for male and female donors, 42 separately. Associations of ferritin levels with subsequent iron deficiency and/or low haemoglobin 43 were assessed with generalized linear mixed models.

44 Results: In both genders two groups of donors were identified using group-based trajectory modelling. 45 Ferritin levels showed rather linear reductions among $42.9 \%$ of male donors and $87.7 \%$ of female 46 donors. For the remaining groups of donors, steeper declines in ferritin levels were observed. Ferritin 47 levels at baseline and the end of follow-up varied greatly between groups.

48 Conclusion: Repeated ferritin measurements show depleting iron stores in all new whole blood 49 donors, the level at which mainly depends on baseline ferritin levels. Tailored, less intensive donation 50 strategies might help to prevent low iron in donors, and could be supported with ferritin monitoring 51 and/or iron supplementation. 
medRxiv preprint doi: https://doi.org/10.1101/2021.12.13.21267744; this version posted December 14, 2021. The copyright holder for this

\section{Introduction}

Repeated whole blood donations often result in low iron stores, potentially leading to donor deferral for low hemoglobin $(\mathrm{Hb})$ and iron deficiency-related symptoms [1-3]. With the reporting of negative findings on the health and availability of donors, it is of paramount importance for blood collection centres to gain more insight into whole blood donors' iron status and how low iron stores in blood donors should be managed.

Currently, international consensus on an appropriate policy for donor iron management is lacking [4]. Schotten et al. (2016) have found that ferritin levels on average require at least 180 days to return to pre-donation levels in a sample of 50 male whole blood donors aged 30-50 years [5]. At day 57, in only $32 \%$ of repeat donors and $25 \%$ of new donors ferritin levels returned to pre-donation levels. Optimal donation intervals may differ between donors, depending on the decrease in ferritin levels after a whole blood donation and an individual's capability of restoring ferritin to pre-donation levels. This may be influenced by dietary and supplemental iron intake and other lifestyle behaviours, as well as by genetic traits that affect iron absorption and release [6].

Repeated measurements of ferritin levels over consecutive donations are generally lacking, as ferritin levels are only measured in cross-sectional studies or in policies with limited measurements; at every $5^{\text {th }}$ or $10^{\text {th }}$ donation $[7,8]$. The prevalence of iron deficiency in repeat donors, even in those with normal $\mathrm{Hb}$ levels, is remarkably high [8-12] . In addition, once donors have become iron-deficient, their risk of subsequent $\mathrm{Hb}$ deferral is over tenfold increased [13]. Several investigations have assessed appropriate methods for lowering the rates of $\mathrm{Hb}$ deferrals, among which a recent study that assessed changes in $\mathrm{Hb}$ levels through repeated donations to identify donors at risk for quick declines in $\mathrm{Hb}$ levels [14]. Hb level recovery in donors depends on the availability of iron $[15,16]$. Hence, insights into changes in ferritin levels over consecutive donations are needed to better understand how quickly iron deficiency develops, and whether or not this differs inter-individually. Eventually this could aid in the development of better tailored donor deferral strategies.

We therefore aimed at distinguishing ferritin trajectories based on measurements of ferritin levels from samples collected during consecutive whole blood donations over a 2-year time period. Additionally, 
medRxiv preprint doi: https://doi.org/10.1101/2021.12.13.21267744; this version posted December 14, 2021. The copyright holder for this preprint (which was not certified by peer review) is the author/funder, who has granted medRxiv a license to display the preprint in perpetuity. All rights reserved. No reuse allowed without permission.

79 we investigated risks of donors returning to donate with low iron levels, defined as either being iron80 deficient or deferred for low $\mathrm{Hb}$, in relation to ferritin levels at the preceding donation. 
medRxiv preprint doi: https://doi.org/10.1101/2021.12.13.21267744; this version posted December 14, 2021. The copyright holder for this

\section{Methods}

82

83

84

85

86

87

88

89

90

91

92

93

94

95

96

97

98

99

100

101

102

103

104

105

106

107

108

\section{Study population}

Sanquin is by law the only organisation authorised for the collection and supply of blood (products) in the Netherlands. All donors undergo routine eligibility testing prior to donating, and plasma samples from every donation are stored for 2 years for quality control purposes. In January 2020, we retrospectively included 300 new donors, who donated at least twice in the two years follow up period from September $11^{\text {th }} 2017$ onwards, in an observational cohort study. We only selected donors who donated at centres that did not implement Sanquin's ferritin measurement policy before September 2019. Pseudonymized blood donor data, including age, sex, Hb levels, number of donations, height and weight were obtained from the donor database (eProgesa software application; MAK-SYSTEMS, Paris, France). Samples were analysed only from voluntary, non-remunerated, adult donors who provided written informed consent as part of routine donor selection and blood collection procedures. Sanquin's Ethical Advisory Board reviewed and approved the study protocol.

\section{Ferritin measurements}

Sanquin's National Screening Laboratory routinely stores $850 \mu \mathrm{L}$ from blood samples collected in K3EDTA tubes (Greiner) taken from the sampling pouch at each whole blood donation. These samples are pipetted into 96 well plates and stored for 2 years at $-30 \square$ C. One day before testing, plates containing selected samples were defrosted. The TECAN pipetting robot (TECAN Trading AG, Switzerland) was used for pipetting selected samples from wells to sample tubes and ferritin levels were determined by the Architect i2000sr (Abbott Diagnostics). For the validation of ferritin levels from stored samples, we compared ferritin levels from stored samples with ferritin levels measured in fresh samples (see Supplement). This showed a slight underestimation of ferritin levels $(-4.4 \mathrm{ng} / \mathrm{ml}$ on average) and differences between measurements mainly ranging from -30.1 to $21.3 \mathrm{ng} / \mathrm{ml}$ (limits of agreement). Measurement differences were larger with higher ferritin levels. At Sanquin, all donors undergo a screening visit before being invited to make their first donation. As ferritin levels were measured twice before the first donation the mean ferritin level was used as baseline level. 
medRxiv preprint doi: https://doi.org/10.1101/2021.12.13.21267744; this version posted December 14, 2021. The copyright holder for this preprint (which was not certified by peer review) is the author/funder, who has granted medRxiv a license to display the preprint in perpetuity.

All rights reserved. No reuse allowed without permission.

\section{Statistical analysis}

111 The donor characteristics were described as medians and interquartile ranges, or as percentages in case of proportions, stratified by gender. To capture the longitudinal trajectories of ferritin levels and the variation in these trajectories among donors, we applied growth mixture models $[17,18]$. Growth mixture models are used to assign individuals to one of several subgroups (latent classes) based on temporal patterns in the data. In this case, donors with similar ferritin trajectories are assigned to one subgroup, and the subgroups are most different from each other in terms of ferritin trajectories.

We conducted the analyses in several steps. First, the heterogeneity of individual ferritin trajectories was visualized and assessed by plotting variations in ferritin levels through the donation time points for all study subjects (spaghetti plots). To identify clusters of donors with a similar pattern of ferritin levels over the repeated donation times within two years, we conducted growth mixture models [1821]. We considered the ferritin levels as a dependent variable and donation numbers in two years (September 2017-September 2019) as the main independent variable. Given the fact that a finite set of polynomial functions of time could summarize the individual differences in trajectories, we fitted the first order linear and second order quadratic polynomial models. Bayesian Information Criterion (BIC) was applied to compare the less complex model (i.e. smaller number of latent classes) to the complex model (i.e. more classes) [22] and logarithm of the Bayes factor $(2 * \Delta B I C)$, where $\triangle \mathrm{BIC}=\mathrm{BIC}$ (complex) - BIC (less complex) [23]. Also, when the absolute value of the logarithm of the Bayes factor $2 * \Delta \mathrm{BIC}$ would indicate trivial $(0-2)$, positive (2-6), strong (6-10) or very strong $(>10)$, this provides the level of evidence for the null hypothesis that the less complex model is the best fit. In the first step we assessed a single quadratic polynomial trajectory model. We conducted a quadratic twotrajectory model if the quadratic component in one trajectory model was significant. The model was repeated with a linear trajectory, if the quadratic term was not significant, to determine the BIC value. The BIC value of the appropriate two $\square$ trajectory model was compared to the BIC value of the appropriate one $\square$ trajectory model and the procedure was repeated by increasing the number of trajectories until the best-fitting model. We stopped the modeling once $\triangle \mathrm{BIC}$ became a negative value.

136 Given the possible confounding effect of varying donation intervals on ferritin levels, we also 
medRxiv preprint doi: https://doi.org/10.1101/2021.12.13.21267744; this version posted December 14, 2021. The copyright holder for this preprint (which was not certified by peer review) is the author/funder, who has granted medRxiv a license to display the preprint in perpetuity. All rights reserved. No reuse allowed without permission.

137 conducted the trajectory analyses with adjustment for time since the previous donation. To assess the 138 effect of ferritin level distributions on the trajectory modeling the analyses were also conducted with 139 log-transformed ferritin levels.

140 After assigning all donors to one of several trajectories, the characteristics of donors with differing

141 ferritin trajectories were described as medians and interquartile ranges, or percentages in case of 142 proportions, stratified by gender. The characteristics of the donors in differing trajectories in each 143 gender, were compared using Mann Whitney U test for continuous variables and Pearson's Chi144 square test for categorical variables.

145 Associations between ferritin levels at a certain donation and subsequent low iron level was assessed 146 by generalized linear mixed models adjusted for age, sex and time since previous donation (a low iron 147 was defined as ferritin levels $<15 \mathrm{ng} / \mathrm{ml}$, or low- $\mathrm{Hb}$ deferral with $\mathrm{Hb}$ levels $<8.4 \mathrm{mmol} / \mathrm{L}$ for men or $148<7.8 \mathrm{mmol} / \mathrm{L}$ for women, corresponding with 135 and $125 \mathrm{~g} / \mathrm{L}$, respectively). Receiver operating 149 characteristic (ROC) analysis was applied to compute the sensitivity and specificity of different 150 ferritin levels for the prediction of subsequent low iron levels. The analyses were conducted in IBM 151 SPSS Statistics for Windows, Version 26.0. Armonk, NY: IBM Corp and Traj module in STATA 152 version 16 for windows (StataCorp. 2019. Stata Statistical Software: Release 16. College Station, TX: 153 StataCorp LLC.). 
medRxiv preprint doi: https://doi.org/10.1101/2021.12.13.21267744; this version posted December 14, 2021. The copyright holder for this preprint (which was not certified by peer review) is the author/funder, who has granted medRxiv a license to display the preprint in perpetuity. All rights reserved. No reuse allowed without permission.

154 Results

155 In total, 300 donors were included in the study, of whom 101 (33.7\%) were male. Male donors on 156 average made 4 donations within two years (median number of donations, IQR=2 to 6) and female 157 donors 3 (IQR=2 to 4), enabling the analysis of 1447 stored samples from successful donations. The median age of male donors was 29.96 years $(\mathrm{IQR}=25.08$ to 38.12) and of female donors 24.62 years (IQR=22.58 to 29.60). Median levels of ferritin at baseline were $103.35 \mu \mathrm{g} / \mathrm{L}$ (IQR= 56.77 to 137.76 ) and $28.13 \mu \mathrm{g} / \mathrm{L}(17.80$ to 43.24$)$ at the last donation for male donors. Among female donors the median ferritin levels at first and last donations were $36.66(\mathrm{IQR}=23.21$ to 56.59$)$ and $13.04 \mu \mathrm{g} / \mathrm{L}$ $(\mathrm{IQR}=10.63$ to 29.30$)$, respectively (Table 1$)$.

The spaghetti plots in Figure 1 demonstrate the individual crude changes in ferritin levels by number of donations. According to the smallest BIC and the logarithm of the Bayes factor, a two-group ferritin level trajectory model (separately) for male and female donors was very strongly favoured. The findings were similar with log-transformed ferritin levels, therefore results on non-transformed data are shown to enable easier interpretation. In male donors, the value of logarithm of the Bayes factor was $18.46(>10)$, therefore, favouring the two-cluster model over a three-cluster model. In female donors, the value of logarithm of the Bayes factor was $88.46(>10)$, favouring the three-trajectory model over a four-cluster model, however due to the small proportion of observations in the third cluster $(<5 \%)$, the two-cluster model was more appropriate. The final analyses confirmed that models with two latent classes fit the data best, for both male and female donors, both with and without adjustment for donation intervals (Figures 2A and 2B). Class I, encompassing 42.9\% of male donors and $87.7 \%$ of female donors, represent a linear reduction in ferritin levels, with a rather mild slope at earlier donations, later leading to steady ferritin levels. Despite a mild linear reduction in ferritin levels in class one, it is worth noticing that donors in this class from both genders have relatively low ferritin levels at baseline. In class two, baseline ferritin levels are relatively high, and there are more drastic reductions in ferritin levels over repeated donations. The donors in class one (with relatively low baseline levels of ferritin) are younger, have lower BMI, have lower ferritin levels at baseline and after two years, and have shorter donation intervals as compared to the donors in class two (Table 2). 
medRxiv preprint doi: https://doi.org/10.1101/2021.12.13.21267744; this version posted December 14, 2021. The copyright holder for this preprint (which was not certified by peer review) is the author/funder, who has granted medRxiv a license to display the preprint in perpetuity. All rights reserved. No reuse allowed without permission.

181 The odds for iron deficiency, at any timepoint for the next donation, among donors with ferritin levels 182 of $<30 \mathrm{ng} / \mathrm{ml}$, were 1.43 to 3.83 -fold higher in comparison to those with ferritin levels of $>30 \mathrm{ng} / \mathrm{ml}$

183 (Table 3). Based on the ROC curve of subsequent iron deficiency or low $\mathrm{Hb}$ detection at different

184 ferritin levels, ferritin levels between 25 and $30 \mathrm{ng} / \mathrm{ml}$ showed both the sensitivity and specificity to be 185 above $70 \%$ (Figure 3).

186 
medRxiv preprint doi: https://doi.org/10.1101/2021.12.13.21267744; this version posted December 14, 2021. The copyright holder for this

preprint (which was not certified by peer review) is the author/funder, who has granted medRxiv a license to display the preprint in perpetuity.

All rights reserved. No reuse allowed without permission.

\section{Discussion}

188 In this study among 300 new whole blood donors whose ferritin levels were measured retrospectively and repeatedly over donations during a period of 2 years, we found two latent classes of ferritin trajectories for separately genders. All trajectories show declining ferritin levels, which vary in baseline ferritin levels and slope. Additionally, we found that low ferritin levels ( $<30 \mathrm{ng} / \mathrm{ml}$ ), if not acted upon, are significantly associated with a subsequent increased risk of returning to donate while iron-deficient or having low Hb levels.

Generally, in male and female donors, it appears that all donors show some level of decline in ferritin levels, and the degree of this decline may depend on baseline ferritin levels. Based on previous studies showing a high prevalence of iron deficiency in repeat donors, and a relatively long recovery of iron stores, this finding might not be very surprising $[1,5,9,24]$. While Hb levels may remain stable over consecutive donations, iron stores continue to be depleted which remains unnoticed when ferritin levels are not measured $[13,14]$. The finding that this decline is steeper with higher baseline ferritin levels can probably be explained by hepcidin levels only being downregulated in case of an iron shortage, in order to increase iron absorption and release [25].

Among men, a minority of donors with high baseline ferritin levels showed relatively fast declines in ferritin levels. Among these donors, the levels of ferritin generally dropped to levels of iron deficiency after 6 to 10 donations. For the group with lower baseline ferritin levels, a less steep linear reduction was observed in ferritin levels, but also after 3-4 donations on average the level of iron deficiency was reached. Adjusting the models for donation intervals resulted in two trajectories with more similar starting points and slopes, indicating that the donation interval is often shorter in donors with high baseline ferritin levels and as a result show more steeply declining ferritin levels.

Female donors who were assigned to the trajectory with more steeply declining ferritin levels were of older age and had higher baseline ferritin levels than those in the other latent class. The higher baseline iron status among women of older age is in line with expectations and probably due to the cessation of menstrual blood loss after menopause [15]. Female donors with high baseline ferritin 
medRxiv preprint doi: https://doi.org/10.1101/2021.12.13.21267744; this version posted December 14, 2021. The copyright holder for this preprint (which was not certified by peer review) is the author/funder, who has granted medRxiv a license to display the preprint in perpetuity. All rights reserved. No reuse allowed without permission.

214 those with lower baseline levels dropped to below this level after 4 donations. Adjusting for donation 215 intervals resulted in a more gradual slope of reductions in ferritin levels.

216 In earlier studies, prediction models for $\mathrm{Hb}$ levels and low-Hb deferrals were developed [26, 27].

217 These models included regression models, transition models, or a combination of these two 218 approaches for predicting $\mathrm{Hb}$ levels based on routinely collected information on blood donors and 219 their donations [26]. The findings from Donor InSight presented four different $\mathrm{Hb}$ trajectories among 5388 new? donors [26]. The latter suggests that relying on a single trajectory for describing changes in $\mathrm{Hb}$ levels of donors through successive donations is not a suitable approach for dealing with the underlying changes in iron status among this population.

A major strength of the study is that ferritin levels were measured retrospectively at every donation over a period of two years. This allowed for detecting trajectories of iron stores among donors, presenting both inter- and intra-individual differences in ferritin levels over repeated donations. Moreover, this enabled showing that low ferritin not only predicts subsequent low $\mathrm{Hb}$, but also iron deficiency [13]. Yet, our study suffered from a limited sample size, which calls for future studies with larger sample sizes to verify these results. Another limitation, applying to any study on ferritin levels, is the fact that ferritin measurements, despite being calibrated in collaboration with other laboratories, are not standardized internationally. This may hamper external validity and thus generalizability of ferritin levels and the cut-offs in particular.

Symptoms that are frequently related to whole blood donation-induced low iron include decreased physical endurance and work capacity, fatigue, and impairment in concentration, attention, and other cognitive functions as well as restless leg syndrome and craving and consuming of non-nutritive substances (pica) [28-36]. Given the significant magnitude of undesired effects of blood donationinduced iron depletion, with on the other hand the high impact on donor availability when deferring too many donors, it is of high importance to determine appropriate cut-off levels for ferritin-guided donor deferrals. The results of our study showed ferritin levels of $25-30 \mathrm{ng} / \mathrm{ml}$ to have the highest sensitivity and specificity for subsequent low iron (defined as ferritin levels $<15 \mathrm{ng} / \mathrm{ml}$ or $\mathrm{Hb}$ deferral). 
medRxiv preprint doi: https://doi.org/10.1101/2021.12.13.21267744; this version posted December 14, 2021. The copyright holder for this preprint (which was not certified by peer review) is the author/funder, who has granted medRxiv a license to display the preprint in perpetuity. All rights reserved. No reuse allowed without permission.

242 on previous findings, these groups might differ in terms of genetic predisposition to differences in iron

243 metabolism and of lifestyle behaviours [15, 37-39]. In future studies, carefully modelling the interplay

244 between iron stores and Hb levels, thereby also considering individual differences in demographics,

245 lifestyle behaviours and -if appropriate- environmental influences, could help to better predict low iron

246 and develop tailored donor iron management strategies.

247 Proposed strategies for donors at risk of low iron might be to increase donation intervals in order

248 to prevent rapid reductions in iron stores through successive donations. Making 5 or 6 donations

249 within two years might not result in iron deficiency or low-Hb deferrals in men and women with high

250 baseline ferritin levels. As a proper strategy for maintaining iron stores among risk groups, it might be

251 helpful to restrict donations to four per two years in this subgroup. Iron supplementation could aid to

252 increase donation intensities without inducing risks of low iron [40]. In addition, ferritin level

253 monitoring could help to monitor and adjust individual donor strategies.

254

\section{Conclusion}

256 In conclusion, repeated ferritin measurements show depleting iron stores in all new whole blood

257 donors, the level of which depends on baseline ferritin levels. Tailored, less intensive donation

258 strategies might help to prevent low iron in donors, and could be supported with ferritin monitoring 259 and iron supplementation. 
medRxiv preprint doi: https://doi.org/10.1101/2021.12.13.21267744; this version posted December 14, 2021. The copyright holder for this preprint (which was not certified by peer review) is the author/funder, who has granted medRxiv a license to display the preprint in perpetuity. All rights reserved. No reuse allowed without permission.

260 Table 1. Descriptive of donors included in the FIND+ dataset: new whole blood donors with more than two 261 blood donations between September 2017 and September 2019. ${ }^{1}$

\begin{tabular}{lcc}
\hline Variables & Male donors $(\mathbf{n}=\mathbf{1 0 1})$ & Female donors $(\mathbf{n}=\mathbf{1 9 9})$ \\
\hline Age $($ years $)$ & $29.96(25.08-38.12)$ & $24.62(22.58-29.60)$ \\
\hline BMI $\left(\mathrm{kg} / \mathrm{m}^{2}\right)$ & $24.22(22.48-26.10)$ & $23.14(21.55-26.44)$ \\
\hline Number of donations & $4(2-6)$ & $3(2-4)$ \\
\hline Hb at screening visit $(\mathrm{mmol} / \mathrm{l})$ & $9.30(8.90-9.60)$ & $8.30(8.00-8.70)$ \\
\hline Baseline ferritin levels $(\mathrm{ng} / \mathrm{ml})$ & $103.35(56.77-137.76)$ & $36.66(23.21-56.59)$ \\
Ferritin at last donation ${ }^{2}(\mathrm{ng} / \mathrm{ml})$ & $28.13(17.80-43.24)$ & $13.04(10.63-29.30)$ \\
\hline Inter-donation interval $(\mathrm{weeks})$ & $37.00(19.00-63.00)$ & $46.00(24.00-69.00)$ \\
\hline Donation in cold seasons $(\%)$ & 47.1 & 48.2
\end{tabular}

${ }^{1}$ The variables are presented as median and interquartile range or as stated otherwise.

${ }^{2}$ Ferritin levels at $6^{\text {th }}$ donation in men and $4^{\text {th }}$ donation in women during study period (September 2017September 2019). 

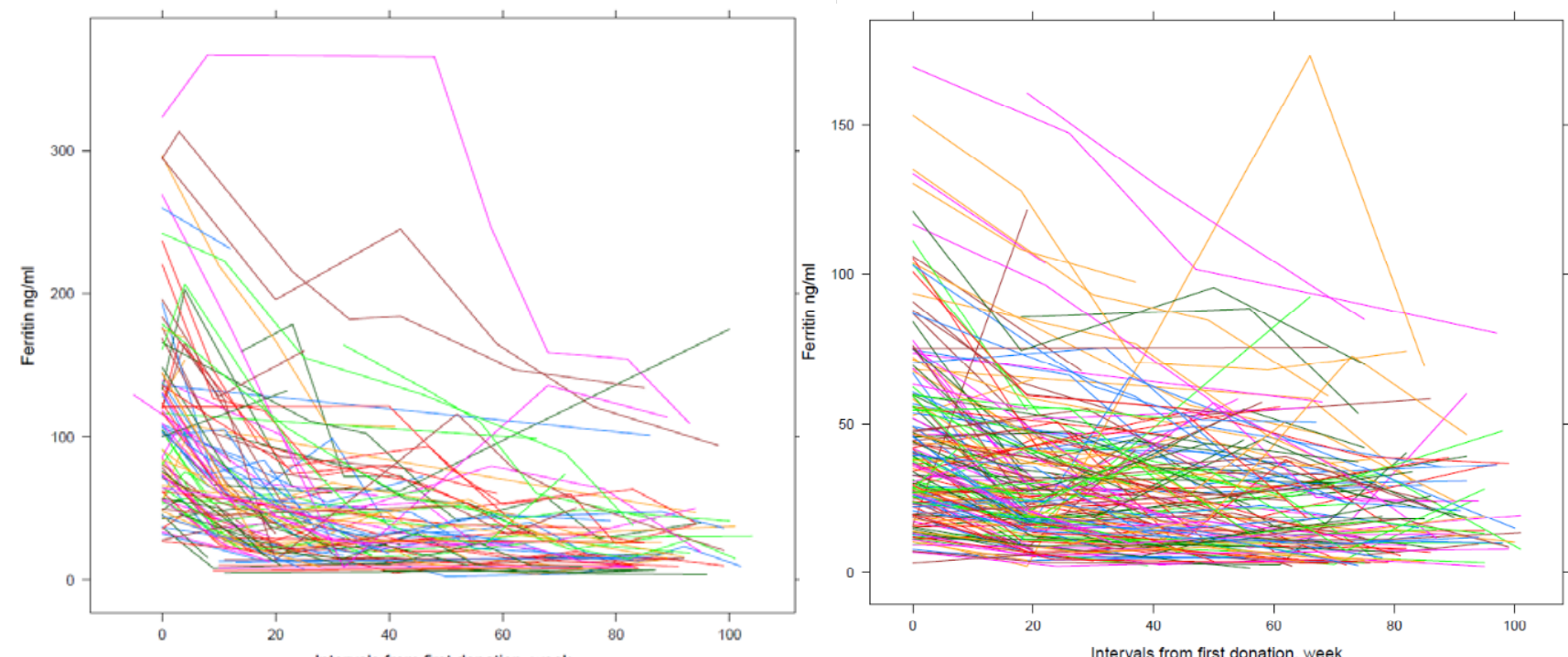

Figure 1. Spagnettı plots demonstrating terralitın leveis over repeated donatıons per individual male (left) and female donor (right) in the FIND+ study by time since baseline, September 2017_September 2019. 

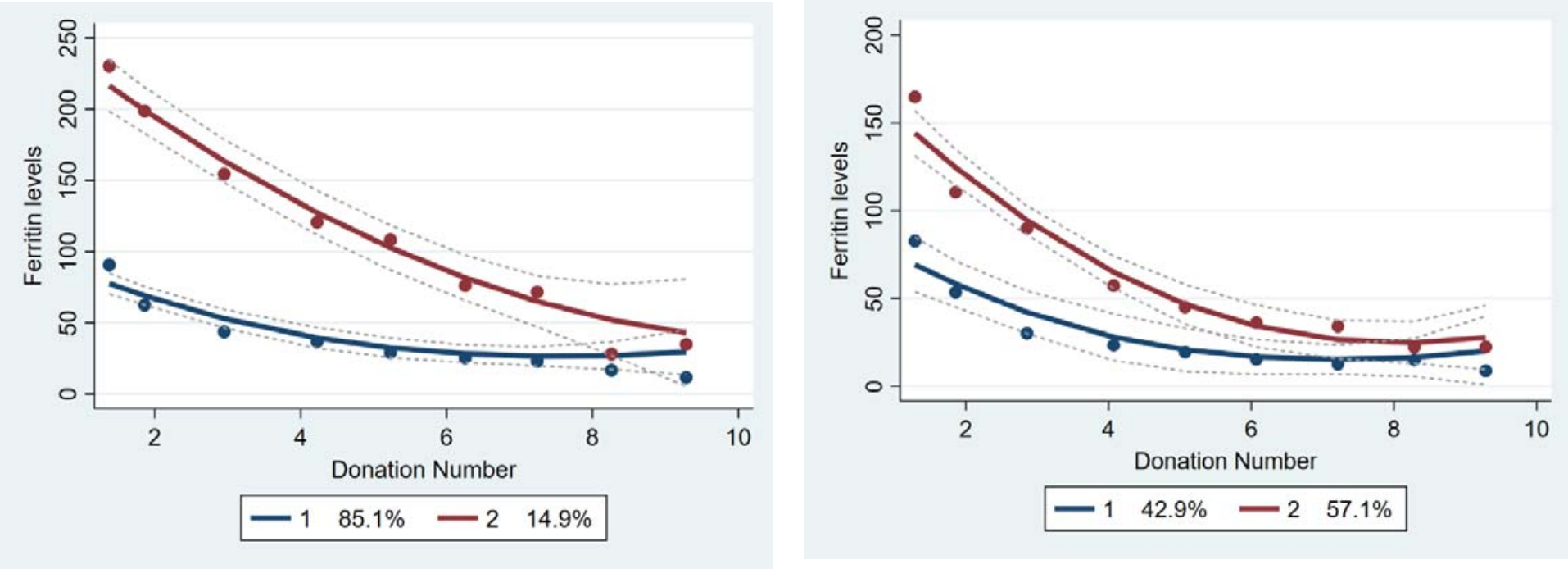

Figure 2A. Group based trajectory analyses exhibiting changes in ferritin levels by donation number in each of the latent classes for male donors in unadjusted models (left) and models adjusted for time since the previous donation (right) in the FIND+ study, September 2017_September 2019. 

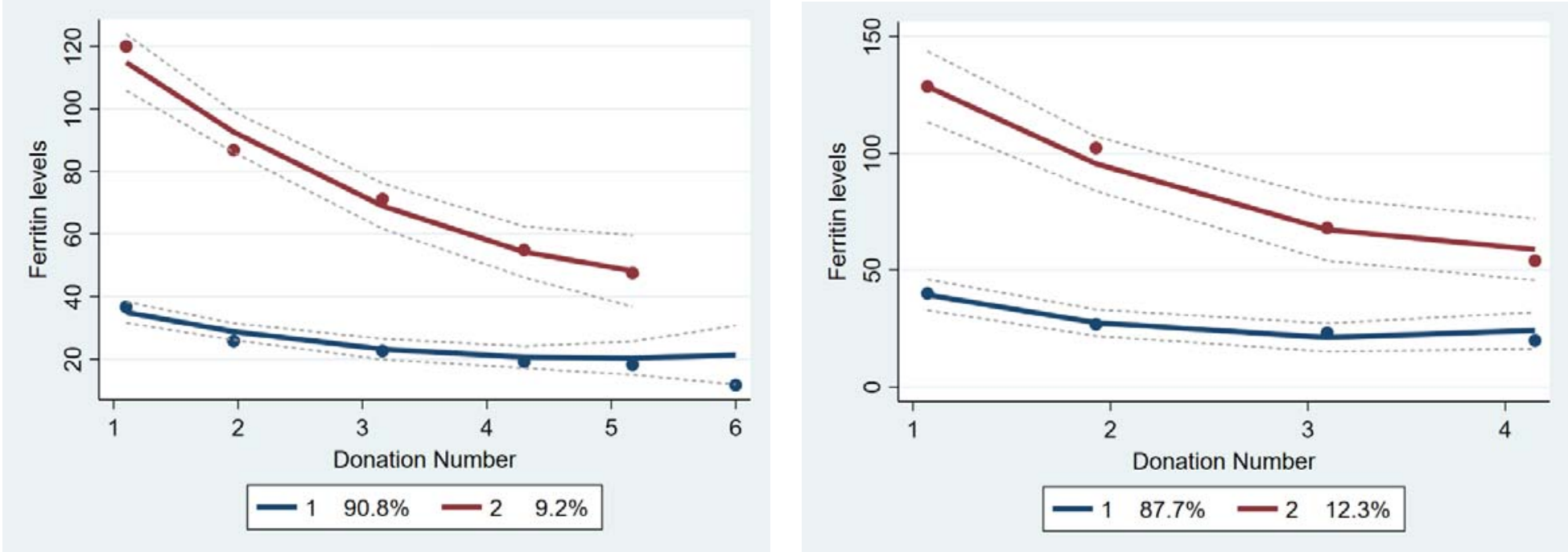

Figure 2B. Group based trajectory analyses exhibiting changes in ferritin levels by donation number in each of the latent classes for female donors in unadjusted models (left) and models adjusted for time since the previous donation (right) in the FIND+ study, September 2017_September 2019. 
Table 2. Descriptive of donors in the FIND+ dataset by gender and group-based trajectory of the growth mixture model ${ }^{1}$

\begin{tabular}{|c|c|c|c|c|}
\hline \multirow[b]{2}{*}{ Variables } & \multicolumn{2}{|c|}{ Male donors } & \multicolumn{2}{|c|}{ Female donors } \\
\hline & Class $1(n=87)$ & Class $2(n=14)$ & Class $1(n=181)$ & Class $2(n=18)$ \\
\hline Age (years) & $28.11(24.82-34.27)$ & $39.43(31.74-47.64)$ & $24.42(22.36-27.98)$ & $35.00(27.28-47.59)$ \\
\hline $\mathrm{BMI}\left(\mathrm{kg} / \mathrm{m}^{2}\right)$ & $23.86(22.15-25.69)$ & $27.46(24.81-28.34)$ & $22.85(21.48-26.23)$ & $25.18(23.23-29.04)$ \\
\hline Number of donations & $4(2-6)$ & $4(2-6)$ & $3(2-4)$ & $3(2-5)$ \\
\hline $\mathrm{Hb}$ at screening visit $(\mathrm{ng} / \mathrm{ml})$ & $9.40(8.90-9.80)$ & $9.05(8.82-9.65)$ & $8.30(8.00-8.80)$ & $8.35(8.17-8.55)$ \\
\hline Ferritin at screening visit $(\mathrm{ng} / \mathrm{ml})$ & $85.40(56.10-120.24)$ & $239.62(181.63-294.61)$ & $32.69(20.34-48.90)$ & $114.13(102.55-135.31)$ \\
\hline Ferritin at last donation $2(\mathrm{ng} / \mathrm{ml})$ & $24.89(14.16-31.10)$ & $53.26(43.78-133.74)$ & $13.52(6.30-28.46)$ & $53.45(39.01-68.89)$ \\
\hline Inter-donation interval (weeks) & $37(19.00-62.00)$ & $42(20.00-71.00)$ & $45(24.00-69.00)$ & $48(22.00-69.00)$ \\
\hline
\end{tabular}

${ }^{1}$ The variables are presented as median and interquartile range or as stated otherwise.

2 Ferritin levels at $6^{\text {th }}$ donation in men and $4^{\text {th }}$ donation in women during study period (September 2017 -September 2019 ).

${ }^{3} \mathrm{P}$-Value are calculated using Mann Whitney U test for continuous variables and Pearson's Chi-square test for categorical variables. 
medRxiv preprint doi: https://doi.org/10.1101/2021.12.13.21267744; this version posted December 14, 2021. The copyright holder for this preprint (which was not certified by peer review) is the author/funder, who has granted medRxiv a license to display the preprint in perpetuity. All rights reserved. No reuse allowed without permission.

Table 3. Associations between ferritin levels and subsequent low iron levels (ferritin levels $<15 \mathrm{ng} / \mathrm{ml}$ or low-Hb deferral) at any of the first 4 donations over 895 whole blood donations, made by 300 donors in

\begin{tabular}{lllll}
\hline Donor ferritin levels (ng/ml) & $\mathrm{N}^{2}$ & Odds Ratio & 95\% Confidence interval & P-value \\
\hline Ferritin levels $<15$ & $99 / 193$ & 3.83 & 3.19 to 4.48 & $<0.001$ \\
\hline Ferritin levels 15-19.9 & $26 / 82$ & 2.44 & 1.73 to 3.15 & $<0.001$ \\
\hline Ferritin levels 20.1-24.9 & $15 / 62$ & 2.10 & 1.31 to 2.89 & $<0.001$ \\
\hline Ferritin levels 25-29.9 & $16 / 85$ & 1.45 & 0.71 to 2.22 & 0.08 \\
\hline Ferritin levels $>30$ & $20 / 473$ & Ref & Ref & - \\
\hline
\end{tabular}

total.

The odds ratios and confidence intervals are calculated using generalized linear mixed models adjusted for age, gender and time since previous donation. Low iron was defined as ferritin levels $<15 \mathrm{ng} / \mathrm{ml}$, or low-Hb deferral: $\mathrm{Hb}$ levels $<8.4 \mathrm{mmol} / \mathrm{L}$ for men or $<7.8 \mathrm{mmol} / \mathrm{L}$ for women, corresponding with 135 and $125 \mathrm{~g} / \mathrm{L}$, respectively. 1 , Indicate the level of ferritin at subsequent donation

2. Indicated number of donations 
medRxiv preprint doi: https://doi.org/10.1101/2021.12.13.21267744; this version posted December 14, 2021. The copyright holder for this preprint (which was not certified by peer review) is the author/funder, who has granted medRxiv a license to display the preprint in perpetuity. All rights reserved. No reuse allowed without permission.

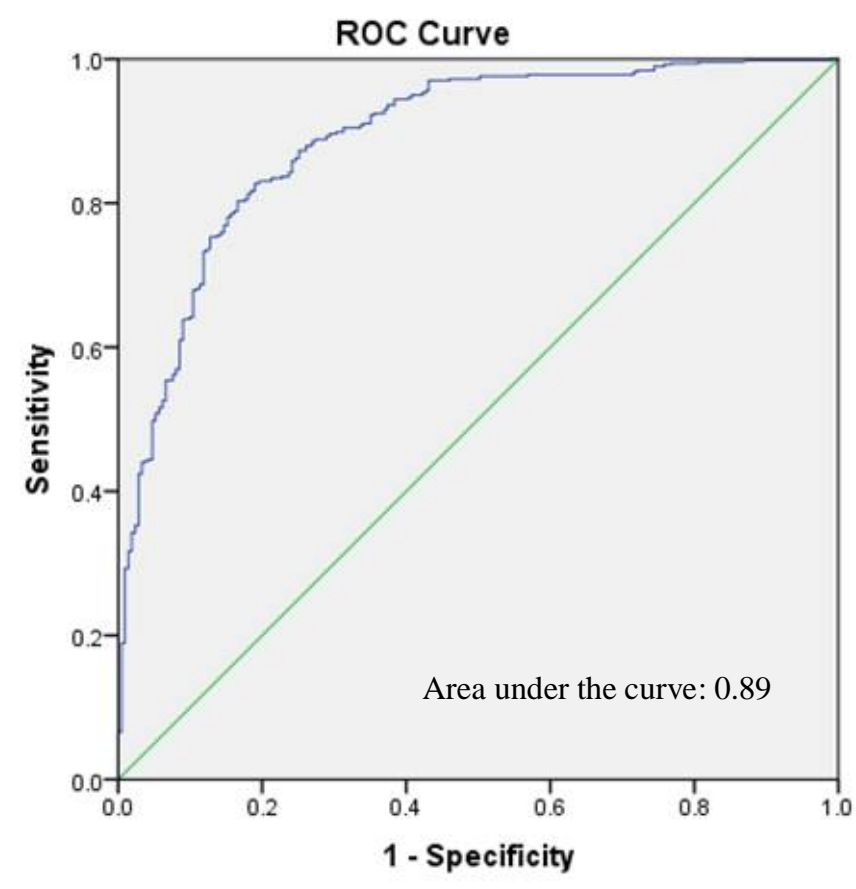

\begin{tabular}{|l|l|l|}
\hline $\begin{array}{l}\text { Ferritin levels } \\
(\mathrm{ng} / \mathrm{ml})\end{array}$ & $\begin{array}{l}\text { Sensitivity } \\
(\%)\end{array}$ & $\begin{array}{l}\text { Specificity } \\
(\%)\end{array}$ \\
\hline 15 & 95.0 & 62.1 \\
\hline 25 & 85.9 & 76.0 \\
\hline 30 & 77.1 & 84.0 \\
\hline
\end{tabular}

Diagonal segments are produced by ties.

Figure 3. Receiver operating characteristic curve for predicting low iron (defined as ferritin $<15$ $\mathrm{ng} / \mathrm{ml}$ or low-Hb deferral) at a subsequent donation attempt based on ferritin levels at any of the first 4 donations in new whole blood donors. 


\section{References:}

1. Spencer, B., Blood donor iron status: are we bleeding them dry? Curr Opin Hematol, 2013. 20(6): p. 533-9.

2. Zalpuri, S., et al., Iron deficiency-related symptoms in whole blood donors: a systematic review. Transfusion, 2019. 59(10): p. 3275-3287.

3. Kiss, J.E. and R.R. Vassallo, How do we manage iron deficiency after blood donation? $\mathrm{Br} J$ Haematol, 2018. 181(5): p. 590-603.

4. Zalpuri, S., et al., Variations in hemoglobin measurement and eligibility criteria across blood donation services are associated with differing low-hemoglobin deferral rates: a BEST Collaborative study. Transfusion, 2020. 60(3): p. 544-552.

5. Schotten, N., et al., The donation interval of 56 days requires extension to 180 days for whole blood donors to recover from changes in iron metabolism. Blood, 2016. 128(17): p. 2185-2188.

6. Timmer, T.C., et al., Dietary intake of heme iron is associated with ferritin and hemoglobin levels in Dutch blood donors: results from Donor InSight. Haematologica, 2020. 105(10): p. 2400-2406.

7. Sweegers, M.G., et al., Ferritin measurement IN Donors-Effectiveness of iron Monitoring to diminish iron deficiency and low haemoglobin in whole blood donors (FIND'EM): study protocol for a stepped wedge cluster randomised trial. Trials, 2020. 21(1): p. 823.

8. Baart, A.M., et al., High prevalence of subclinical iron deficiency in whole blood donors not deferred for low hemoglobin. Transfusion, 2013. 53(8): p. 1670-7.

9. Vinkenoog, M., et al., First results of a ferritin-based blood donor deferral policy in the Netherlands. Transfusion, 2020. 60(8): p. 1785-1792.

10. Fillet, A.M., et al., Iron deficiency among French whole-blood donors: first assessment and identification of predictive factors. Vox Sang, 2021. 116(1): p. 42-52.

11. Terada, C.T., et al., Iron deficiency and frequency of HFE C282Y gene mutation in Brazilian blood donors. Transfus Med, 2009. 19(5): p. 245-51.

12. Spencer, B.R., et al., Iron status and risk factors for iron depletion in a racially/ethnically diverse blood donor population. Transfusion, 2019. 59(10): p. 3146-3156.

13. Prinsze, F.J., et al., Donation-induced iron depletion is significantly associated with low hemoglobin at subsequent donations. Transfusion, 2021.

14. Nasserinejad, K., et al., Prevalence and determinants of declining versus stable hemoglobin levels in whole blood donors. Transfusion, 2015. 55(8): p. 1955-63.

15. Baart, A.M., et al., Development and validation of a prediction model for low hemoglobin deferral in a large cohort of whole blood donors. Transfusion, 2012. 52(12): p. 2559-69.

16. Mast, A.E., et al., Hepcidin level predicts hemoglobin concentration in individuals undergoing repeated phlebotomy. Haematologica, 2013. 98(8): p. 1324-30.

17. Mo, W. and T.E. Bodner, Growth Mixture Modeling: Identifying and Predicting Unobserved Subpopulations With Longitudinal Data. Organizational Research Methods, 2007. 10(4): p. 635656.

18. Nagin, D.S. and C.L. Odgers, Group-based trajectory modeling in clinical research. Annu Rev Clin Psychol, 2010. 6: p. 109-38.

19. JONES, B.L., D.S. NAGIN, and K. ROEDER, A SAS Procedure Based on Mixture Models for Estimating Developmental Trajectories. Sociological Methods \& Research, 2001. 29(3): p. 374393.

20. Nagin, D.S., Analyzing developmental trajectories: A semiparametric, group-based approach. Psychological Methods, 1999. 4: p. 139-157.

21. Niyonkuru, C., et al., Group-based trajectory analysis applications for prognostic biomarker model development in severe TBI: a practical example. J Neurotrauma, 2013. 30(11): p. 938-45.

22. G., S., Estimating the dimension of a model. Ann Stat 1978;6:461-464. 
23. Wit, E.C., E.v.d. Heuvel, and J.-W. Romeijn, All models are wrong...: an introduction to model uncertainty. American Journal of Botany, 2012.

24. Mantilla-Gutiérrez, C.Y. and J.A. Cardona-Arias, [Iron deficiency prevalence in blood donors: a systematic review, 2001-2011]. Rev Esp Salud Publica, 2012. 86(4): p. 357-69.

25. Yook, J.S., et al., Essential role of systemic iron mobilization and redistribution for adaptive thermogenesis through HIF2- $\alpha$ /hepcidin axis. Proc Natl Acad Sci U S A, 2021. 118(40).

26. Nasserinejad, K., et al., Predicting hemoglobin levels in whole blood donors using transition models and mixed effects models. BMC Med Res Methodol, 2013. 13: p. 62.

27. Baart, A.M., et al., Prediction of low haemoglobin levels in whole blood donors. Vox Sang, 2011. 100(2): p. 204-11.

28. Brittenham, G.M., Iron deficiency in whole blood donors. Transfusion, 2011. 51(3): p. 458-61.

29. Schiepers, O.J., et al., Serum iron parameters, HFE C282Y genotype, and cognitive performance in older adults: results from the FACIT study. J Gerontol A Biol Sci Med Sci, 2010. 65(12): p. 1312-21.

30. Dallman, P.R., Biochemical basis for the manifestations of iron deficiency. Annu Rev Nutr, 1986. 6: p. 13-40.

31. Newman, B.H., et al., The effect of whole-blood donor adverse events on blood donor return rates. Transfusion, 2006. 46(8): p. 1374-9.

32. Popovsky, M.A., Anemia, iron depletion, and the blood donor: it's time to work on the donor's behalf. Transfusion, 2012. 52(4): p. 688-92.

33. Ulfberg, J. and B. Nyström, Restless legs syndrome in blood donors. Sleep Med, 2004. 5(2): p. $115-8$.

34. Birgegård, G., K. Schneider, and J. Ulfberg, High incidence of iron depletion and restless leg syndrome (RLS) in regular blood donors: intravenous iron sucrose substitution more effective than oral iron. Vox Sang, 2010. 99(4): p. 354-61.

35. Bryant, B.J., et al., Ascertainment of iron deficiency and depletion in blood donors through screening questions for pica and restless legs syndrome. Transfusion, 2013. 53(8): p. 1637-44.

36. Spencer, B.R., et al., Restless legs syndrome, pica, and iron status in blood donors. Transfusion, 2013. 53(8): p. 1645-52.

37. Soranzo, N., et al., A genome-wide meta-analysis identifies 22 loci associated with eight hematological parameters in the HaemGen consortium. Nat Genet, 2009. 41(11): p. 1182-90.

38. van der Harst, P., et al., Seventy-five genetic loci influencing the human red blood cell. Nature, 2012. 492(7429): p. 369-75.

39. Cvejic, A., et al., SMIM1 underlies the Vel blood group and influences red blood cell traits. Nat Genet, 2013. 45(5): p. 542-545.

40. Kiss, J.E., et al., Oral iron supplementation after blood donation: a randomized clinical trial. Jama, 2015. 313(6): p. 575-583. 